million that it has absorbed since it began in 1955 .

Outside the immediate field of cancer research, there is apprehension that too large a proportion of the additional funds in the offing may be devoted to plannable research and too little to basic research which alone can afford a fundamental solution to the cancer problem. "At a certain level the new initiative is a disaster," one eminent biologist said last week, "since three-quarters of the relevant work for cancer is not being done in the name of cancer research. I think the people at the NCI will have to use their heads not to pilfer it all away. If they spend $\$ 50$ million on searching for a virus in breast cancer, or providing electron microscopes in Nebraska, or funding research in cancer centres as a form of psychiatric care for doctors to give them the impression of doing research, then they're going to get nothing for their money."

This gloomy view of the hard road ahead is not shared inside the National Cancer Institute, and indeed Baker, in testimony before the House Appropriations Committee on April 23 last year, stated, "there are many scientifically based reasons for believing that not all but most cancer might be preventable if we are willing to make the investment". This view is subscribed to by other cancer researchers, more than 600 of whom endorsed the resolution introduced last month into the House of Representatives by Congressman Gallagher, calling for a NASA-type conquest of cancer. The 600 cancer researchers subscribed in particular to this statement: "We further express our conviction that with the level of funding and the magnitude of commitment authorized under the Gallagher resolution, cancer can be cured and controlled." It is little wonder that outside the ranks of cancer researchers there are fears of a backlash against all kinds of science from a public conditioned to believe by both politicians and scientists alike that a cancer cure is as attainable as the Moon.

\section{Udall Praises NAS}

by our Washington Correspondent

THERE was praise from an unexpected quarter for the National Academy of Sciences at the hearing held last week by the Department of the Interior on the proposed construction of an oil pipeline across Alaska. Stewart L. Udall, former Secretary of the Interior under the Kennedy and Johnson administrations, criticized the department's recent report recommending in favour of the pipeline and blamed it for having failed to seek advice on the matter from such "superior outside consultants" as the National Academy of Sciences.

Udall, who is head of an environmental consulting agency, known as the Overview Group, last referred to the academy in a speech delivered to the AAAS meeting in Chicago last December. On that occasion he assailed the academy for having failed to speak out earlier and move vociferously in defence of the environment, calling it a puppet of government that only gave the answers it was asked for. These remarks provoked a sharp response from the president of the academy, Dr Philip Handler, who countered that Udall had wholly ignored the academy and its reports on the environment during his secretaryship; "Udall seems to have discovered the environment after he left his post as Secretary of the Interior," Handler said (Nature, 229, 151; 1971). Now, it seems, Udall has discovered the academy in a fresh light; his Alaska hearing speech sounds quite close to an apology.

\title{
Salaries of US Scientists in 1970
}

Scientific and Technical Field
All fields (in dollars)
Chemistry
Earth and Marine Sciences
Atmospheric and Space Sciences
Physics
Mathematics
Computer Sciences
Agricultural Sciences
Biological Sciences
Psychology
Statistics
Economics
Sociology
Political Science
Anthropology
Linguistics

\begin{tabular}{rrrrr}
$\begin{array}{r}\text { Lower } \\
\text { decile } \\
9,500\end{array}$ & $\begin{array}{r}\text { Lower } \\
\text { quartile } \\
11,900\end{array}$ & $\begin{array}{r}\text { Median } \\
15,000\end{array}$ & $\begin{array}{r}\text { Upper } \\
\text { quartile } \\
19,100\end{array}$ & $\begin{array}{l}\text { Upper } \\
\text { decile } \\
24,500\end{array}$ \\
\hline 9,600 & 12,000 & 15,300 & 19,200 & 24,000 \\
10,000 & 12,000 & 14,900 & 18,400 & 23,100 \\
10,000 & 12,700 & 15,200 & 18,400 & 22,300 \\
10,000 & 12,000 & 15,900 & 20,000 & 25,000 \\
9,000 & 11,000 & 14,300 & 19,200 & 25,000 \\
11,800 & 13,600 & 16,500 & 20,000 & 24,000 \\
8,800 & 10,300 & 12,800 & 15,800 & 19,500 \\
8,700 & 11,300 & 15,000 & 20,000 & 26,100 \\
10,500 & 12,300 & 15,000 & 18,500 & 23,700 \\
11,500 & 13,600 & 16,900 & 20,700 & 25,000 \\
11,000 & 13,000 & 16,300 & 21,000 & 27,000 \\
8,500 & 10,400 & 13,000 & 16,700 & 21,000 \\
9,300 & 10,700 & 13,100 & 18,000 & 23,500 \\
10,700 & 12,000 & 14,700 & 18,900 & 23,000 \\
9,000 & 10,500 & 12,500 & 16,400 & 20,700
\end{tabular}

Source-National Register of Scientific and Technical Personnel, 1970.

\section{COMPUTERS}

Honeywell's New Range

THE recent announcement by Honeywell of a new range of computers implies that the company's acquisition of the business computer interests of General Electric (US) has already paid dividends. Honeywell claims that its new ' 6000 ' computers, which are closely related to a series which was nearing production at General Electric before the merger, will give at least 15 per cent more computing power than the IBM machines. And if the IBM policy of "unbundling" (that is, charging separately for software, maintenance and so on) is fully taken into account, the advantages of the Honeywell range could turn out to be much greater. The larger members of the new series also seem to have considerable advantages in computing power over the largest of the ICL ' 1900 ' series; the most powerful of the System 4 series made by ICL (the ' $4 / 72$ ') is equivalent to the middle members of the ' 6000 ' family (the ' 6030 ' and '6040'). Honeywell obviously hopes to increase significantly its share of the British market but the company would be the first to admit that, in the public sector at least, it will have difficulty unseating ICL from its entrenched position.

Three members of the ' 6000 ' series have been specially designed for a mixed scientific and business workload but the other three can offer useful increases in computing capability for customers who will principally be using $\mathrm{COBOL}$, the business language. Honeywell claims that the new series is the first to operate in all the four computing "dimensions", remote and local batch processing, time sharing and transaction processing (of which a good example is the storage of medical records). The four largest systems will also be available with as many as four central processors linked together in such a way that a fail-safe situation is achieved as well as increased throughput; the failure of one processor will no longer have a catastrophic effect.

Programs written for the 6000 series will be compatible with the smaller Honeywell 600 series, but compatibility of peripheral equipment with models made by other companies remains something of a thorny problem. At least one step in the right direction is the adoption of the COBOL programming language by the American Standards Institute as the recommended language for business machines.

Forecasts of the burgeoning state of the computer industry suggest that the value of computers installed throughout the world will double in the next five years to a staggering $£ 31,000$ million. With a ten per cent share of this market, Honeywell is well placed to take advantage of the boom, but the company will have to go a long way to make much impression on the dominance of IBM. 